\title{
On the divergence of early and contemporary HRM theories
}

\author{
Anna Gordon
}

\section{1}

\section{Abstract}

The quest of human for better production and management methods to generate or to raise income is as ancient as time. Adam Smith (1723 - 1790), David Ricardo (1772 - 1823), and Jeremy Bentham (1748 1832) are considered to be the pioneers of modern management theories. The conventional management theories originated in the industrial revolution when technical advances, the expansion of commerce and markets, increasing populations generate mass production opportunities by means of a motorized and systemic method. First, this research reviews three most crucial early works: An Inquiry into the Nature and Causes of the Wealth of Nations" (1776) by Adam Smith (1723 - 1790), "Letter to T. R. Malthus, October 9, 1820" by David Ricardo (1772 - 1823), and "Introduction to the Principles of Morals" (1789) by Jeremy Bentham (1748 - 1832). Second, we compare those early works with modern theories and practices of HRM. We argued that the early theories were built upon materialistic consideration; while, the modern theories are established on both materialistic and humanitarian grounds. The trends in HRM literature showed that we might witness, in coming decades, a surge of theories built on humanitarian principles.

\section{Springer Materials}

Access one of the largest materials science databases in the world, today!

We've agreed an institution-wide subscription to SpringerMaterials. So please spread the word to your colleagues!

SpringerMaterials will save you time searching, so you can start researching with resources you trust. It's intuitive search functionaiity will deliver the data you need with minimal effort.

SpringerMaterials will allow you to:

- View details on $290,000+$ materials

- Access 3,000+ properties

- Export data and citation information in multiple formats

- Engage with interactive graphs, corrosion data sets, phase diagrams, crystal structures and side-by-side comparisons of material properties

- Access major materials science data sources including the Landolt-Börnstein book series, MSI Eureka, and Polymer Thermodynamics Database (ATHAS)

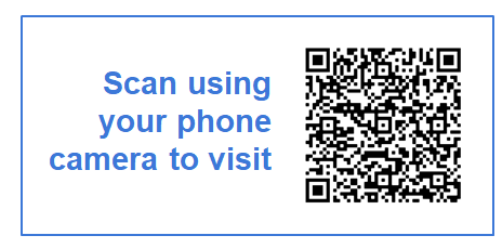

materials.springer.com 


\section{References}

[1] A. Smith, "An inquiry into the wealth of nations," Strahan and Cadell, London, 1776.

[2] A. Sen, "Adam Smith and the contemporary world, " Erasmus J. Philos. Econ., 2010.

[3] V. Benuyenah and M. Phoon, "POPULATION, PROPERTY AND PRODUCTIVITY: A THEORETICAL PREDICTION OF ECONOMIC GROWTH IN VIETNAM.,” J. Glob. Bus. Econ., vol. 8, no. 1, 2014.

[4] V. Benuyenah, "Economics of Social Proximity-Measuring the Deadweight Loss of Tet Gifts."

[5] V. L. Smith, "The Two Faces of Adam Smith," South. Econ. J., 1998.

[6] R. Kramar, "Beyond strategic human resource management: Is sustainable human resource management the next approach?," Int. J. Hum. Resour. Manag. , 2014.

[7] S. Wilkinson and D. Leifer, "Human resource management," in Workplace Strategies and Facilities Management, 2007.

[8] V. Benuyenah, "Conflict perspectives in international business organisations: The changing trends and its management," Manag. Leadersh. Gov., p. 417, 2013.

[9] Z. Hamid, M. Muzamil, and S. A. Shah, "Strategic human resource management," in Handbook of Research on Positive Organizational Behaviorfor Improved Workplace Performance, 2019.

[10] S. H. Hengky, "Fundamentals of Human Resource Management," Journal of Human Resources Management and LaborStudies. 2013.

[11] J. N. Keynes, D. Ricardo, and E. C. K. Gonner, "Principles of Political Economy and Taxation.," Econ. J., 1891.

[12] V. Benuyenah and B. Pandya, "Measuring employee happiness in the UAE-integrating organisational data into the national statistics," Int. Rev. Manag. Mark., vol. 10, no. 3, pp. 83-92, 2020.

[13] D. Ricardo, " From The Principles of Political Economy and Taxation ," 2005.

[14] L. James, "Identifying the effect of Digital Marketing channels on the growth of SME in South Asia: A Case Study on Faheem Haydar Dealzmag," 2020.

[15] E. Fossati, “THE WORKS AND CORRESPONDENCE OF DAVID RICARDO,” Metroeconomica, 1952.

[16] V. Benuyenah and P. B. Tran, "Postpartum psychological pressure on single mothers: an interpretative phenomenological analysis," J. Humanit. Appl. Soc. Sci., 2020.

[17] R. Dorfman, "Thomas Robert Malthus and David Ricardo," J. Econ. Perspect., 1989.

[18] J. Bentham, "An Introduction to the Principles of Morals and Legislation," in Princeton Readings in Political Thought, 2020. 
[19] V. Benuyenah and B. Boukareva, "Making HRM curriculum relevant-a hypothetical practitioners' guide,"J. Work. Manag., 2018.

[20] J. Bentham, "Manual of Political Economy," 2018.

[21] J. Watso, "Bentham," in Jeremy Bentham: Ten Critical Essays, 2013.

[22] S. E. Jackson, D. W. S. Renwick, C. J. C. Jabbour, and M. Muller-Camen, "State-of-the-art and future directions for green human resource management," Ger. J. Res. Hum. Resour. Manag., 2011.

[23] S. Strohmeier, "Research in e-HRM: Review and implications," Hum. Resour. Manag. Rev., 2007.

[24] V. Benuyenah, "Theorising an organisational citizenship behaviour model for managerial decision-making: from history to contemporary application," Manag. Res. Rev., 2021.

[25] C. Guo and A. Al Ariss, "Human resource management of international migrants: current theories and future research," International Journal of Human Resource Management. 2015.

[26] D. W. S. Renwick, C. J. C. Jabbour, M. Muller-Camen, T. Redman, and A. Wilkinson, "Contemporary developments in Green (environmental) HRMscholarship," Int. J. Hum. Resour. Manag., 2016.

[27] C. J. Zhu and M. Warner, "The emergence of Human Resource Management in China: Convergence, divergence and contextual ization," Hum. Resour. Manag. Rev., 2019.

[28] A. C. F. Kwok, "The Evolution of Management Theories: A Literature Review," Nang Yan Bus. J., 2018.

[29] A. A. Arulrajah and H. H. D. N. P. Opatha, "Analytical and Theoretical Perspectives on Green Human Resource Management: A Simplified Underpinning," Int. Bus. Res. , 2016. 